\title{
Article \\ Quinoa for the Brazilian Cerrado: Agronomic Characteristics of Elite Genotypes under Different Water Regimes
}

\author{
Patrícia Carvalho da Silva ${ }^{1}\left(\mathbb{D}\right.$, Walter Quadros Ribeiro Junior ${ }^{2, *}$, Maria Lucrecia Gerosa Ramos ${ }^{1}{ }^{(\mathbb{D}}$, \\ Sonia Maria Costa Celestino ${ }^{2}$, Alberto do Nascimento Silva ${ }^{1}$, Raphael Augusto das Chagas Noqueli Casari ${ }^{3}$, \\ Charles Cardoso Santana ${ }^{1}{ }^{10}$, Cristiane Andrea de Lima ${ }^{1}$, Thomas Christopher Rhys Williams ${ }^{4}$ \\ and Christina Cleo Vinson ${ }^{1}$
}

check for updates

Citation: da Silva, P.C.; Ribeiro Junior, W.Q.; Ramos, M.L.G.; Celestino, S.M.C.; Silva, A.d.N.; Casari, R.A.d.C.N.; Santana, C.C.; de Lima, C.A.; Williams, T.C.R.; Vinson, C.C. Quinoa for the Brazilian Cerrado: Agronomic Characteristics of Elite Genotypes under Different Water Regimes. Plants 2021, 10, 1591. https: / doi.org/10.3390/plants 10081591

Academic Editors: Cataldo Pulvento and Didier Bazile

Received: 7 June 2021

Accepted: 19 July 2021

Published: 2 August 2021

Publisher's Note: MDPI stays neutral with regard to jurisdictional claims in published maps and institutional affiliations.

Copyright: (c) 2021 by the authors. Licensee MDPI, Basel, Switzerland. This article is an open access article distributed under the terms and conditions of the Creative Commons Attribution (CC BY) license (https:/ / creativecommons.org/licenses/by/ $4.0 /)$.
1 Faculdade de Agronomia e Medicina Veterinária, Universidade de Brasília, Brasília 70910970, DF, Brazil; patriciacarvalhoagro@gmail.com (P.C.d.S.); lucreciaunb@gmail.com (M.L.G.R.); albertosilvaagro@gmail.com (A.d.N.S.); ccsantana.agro@gmail.com (C.C.S.); agro.cristiane@gmail.com (C.A.d.L.); ccvinson@unb.br (C.C.V.)

2 Embrapa Cerrados, Empresa Brasileira de Pesquisa Agropecuária, Planaltina 73310970, DF, Brazil; sonia.celestino@embrapa.br

3 Instituto de Geociências, Universidade de Brasília, Brasília 70910970, DF, Brazil; casari.raphael@gmail.com

4 Departamento de Botânica, Instituto de Ciências Biológicas, Universidade de Brasília, Brasília 70910970,DF, Brazil; tcrwilliams@unb.br

* Correspondence: walter.quadros@embrapa.br; Tel.: +55-(61)-3388-9886

Abstract: Quinoa stands out as an excellent crop in the Cerrado region for cultivation in the offseason or irrigated winter season. Here, we tested the effects of different water regimes on the agronomic characteristics, physiology, and grain quality of different elite quinoa genotypes under field conditions. The experiment was conducted under field conditions at Embrapa Cerrados (Planaltina, DF, Brazil). The experimental design was in randomized blocks, in a split-plot scheme, with four replications. The plots were composed of 18 quinoa genotypes and modified BRS Piabiru (the currently used genotype), and the split-plots were divided into 4 different water regimes. The following variables were evaluated: productivity and productivity per unit of applied water (PUAA), plant height, flavonoids, anthocyanins, gas exchange, chlorophyll, leaf proline, and relative water content. Our results showed that water regimes between 309 and $389 \mathrm{~mm}$ can be recommended for quinoa in the Cerrado region. CPAC6 and CPAC13 presented the highest yield and PUAA under high and intermediate WRs, and hence were the most suitable for winter growth under irrigation. CPAC17 is most suitable for off-season growth under rainfed conditions, as it presented the highest PUAA under the low WRs (247 and 150). CPAC9 stood out in terms of accumulation of flavonoids and anthocyanins in all WRs. Physiological analyses revealed different responses of the genotypes to water restriction, together with symptoms of stress under lower water regimes. Our study reinforces the importance of detailed analyses of the relationship between productivity, physiology, and water use when choosing genotypes for planting and harvest in different seasons.

Keywords: Chenopodium quinoa; water use efficiency; phenolic compounds; gas exchange

\section{Introduction}

Crop development and yield are affected by different environmental factors, and water restriction is the most important constraint on agricultural yield [1,2]. This is a particular problem in the Brazilian Cerrado, which has a tropical climate with an average of $1500 \mathrm{~mm}$ of rain, but where approximately $90 \%$ of precipitation occurs during the rainy season (from October to April). The rainy season is followed by a dry season (from May to September), during which the relative humidity is low, the evaporation very high, and precipitation is rare. There are three harvest periods in the Brazilian Cerrado: (1) The main crop season, which occurs during the wet season from October to January; (2) The 
off-season crop, which is grown at the end of wet season without irrigation, is planted between the months of January to March [3,4], and is harvested in May during the dry season; and (3) the winter season crop, which is cultivated under irrigated conditions, with the crop being both planted (April to May) and harvested (August to September) during the dry season. Both the off-season and winter season require careful selection of genotypes for grain production; drought-tolerant genotypes (DT) should be selected for the off-season crop, and high productivity per unit of applied water (PUAA) genotypes are needed for winter crops as they are grown under irrigation. Obtaining genotypes that are better adapted to stressful edaphoclimatic conditions in order to resist periods with water deficiency whilst maintaining the highest possible productivity for each condition is therefore of great importance in plant breeding programs [5].

Quinoa (Chenopodium quinoa Willd.) is a pseudocereal rich in natural antioxidants, flavonoids, and anthocyanins [6,7], and these compounds may protect plants against biotic and abiotic stress [8]. Water stress increases leaf temperature, and reduces crop height, stomatal conductance, plant biomass, and yield [9,10].

Quinoa has been cultivated for millennia under conditions of low rainfall, as it has physiological and morphological strategies to overcome water deficit [11]. Moreover, this crop has been cultivated in different agroclimatic zones as it is well adapted to a variety of different environments due to its high genetic diversity [11]. Quinoa has mainly been cultivated in Argentina, Bolivia, Chile, Colombia, Ecuador, and Peru, though high productivity has also been observed when planted in Kenya as well as the Himalayas and northern plains of India [12].

In Brazil, research carried out in Embrapa Cerrados led to the selection of the genotype BRS Piabiru [3], which is the first cultivar in use for quinoa grain cultivation that is adapted to Cerrado conditions. Although planting quinoa during the main crop is not recommended due to the high water availability during the harvesting period (which can potentially result in panicle seed germination $[3,5]$ ), quinoa is recommended for growth during the off-season or irrigated winter season due to its high water use efficiency, drought tolerance, and adaptation to different environmental conditions.

Here, we therefore analysed growth, yield, and physiological and functional grain parameters, with the aim of identifying genotypes with potential for growth during the off-season and winter season for the Cerrado region.

\section{Material and Methods}

\subsection{Experimental Area Characterization}

The experiment was conducted between May and September 2017 at the experimental station of Embrapa Cerrados-Planaltina DF (Brazil), located between the geographic coordinates: $15^{\circ} 35^{\prime} \mathrm{S}$ and $47^{\circ} 42^{\prime} \mathrm{W}$ with an approximate altitude of $1200 \mathrm{~m}$.

The climate of the region is tropical wet-dry (Aw), according to Köppen's classification [13], with 2 well-defined seasons (dry and rainy). The average annual temperature is $21.3^{\circ} \mathrm{C}$ and the mean annual rainfall $1400 \mathrm{~mm}$. The experiment was conducted in winter due to the absence of rainfall during this period, which allowed for effective control of the amount of water applied. The long-term temperature and rainfall data from the last 20 years (1997 to 2017) are shown in Figure 1 and illustrate the annual dry season during the months of May to September. Temperature and rainfall data from the study period are in good agreement with long-term patterns (Figure 1).

The soil of the experimental area is classified as clayey Oxisol (Typic Haplustox) (Soil Survey Staff 2014), with a soft undulating relief and a clayey texture. The soil has the following characteristics in the $0-20 \mathrm{~cm}$ layer: $\mathrm{pH}$ (in water) $=5.71 ; \mathrm{Ca}\left(\mathrm{mg} \mathrm{kg}^{-1}\right)=543.08$;

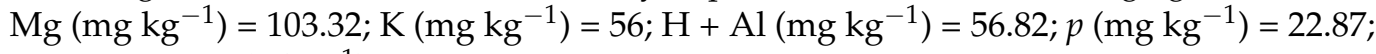
organic matter $\left(\mathrm{g} \mathrm{kg}^{-1}\right)=24.7$. 


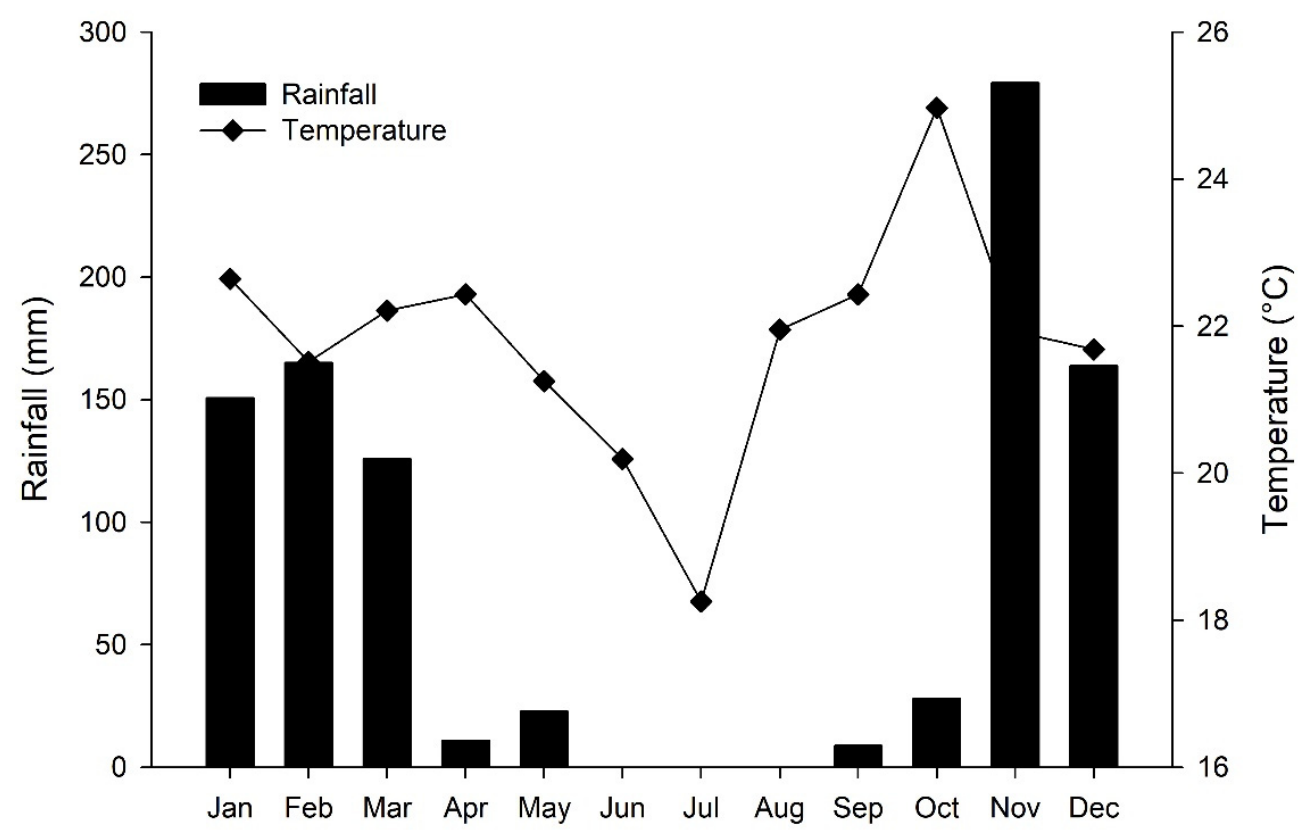

Figure 1. Mean rainfall and temperature in long-term data from the last 20 years (1997-2017).

\subsection{Experimental Design}

Tests with 980 selected genotypes were previously conducted in Cristalina-GO, and genotypes with an early cycle were selected; early cycles were defined as those of equal to or less than 110 days as this is the period for growth in the off-season or irrigated winter season. The experiment was repeated over 4 years; genotypes were sown in the off-season and winter of 2011, 2012, 2013, and 2014, and morphological characteristics were evaluated to obtain morphological descriptors of the genotypes. As a result, 18 genotypes with life cycle equal to or less than 110 days and with seeds larger than $2 \mathrm{~mm}$ in diameter were selected for use in this study: CPAC1, CPAC2, CPAC3, CPAC4, CPAC5, CPAC6, CPAC8, CPAC10, CPAC11, CPAC12, CPAC13, CPAC14, CPAC16, CPAC17, CPAC18, CPAC19, and CPAC20, together with the BRS Piabiru cultivar, which was modified by excluding high-cycle individuals.

The experimental design was in randomized blocks with split-plots with 4 replications. The plots were composed of the 18 quinoa genotypes and modified BRS Piabiru each separated by a distance of $1 \mathrm{~m}$, and the split-plots were composed of 4 water regimes (WRs $150,247,389$, and $480 \mathrm{~mm}$ ). Seeds of the different genotypes of quinoa were sown manually under a no-tillage system. After soil analysis, fertilization was carried out in the furrows at a level of $400 \mathrm{~kg} \mathrm{ha}^{-1}$ of the formula 04-30-16 (NPK). Sowing was done with a density of $0.7 \mathrm{~g}$ of seeds per linear meter and line spacing of $0.5 \mathrm{~m}$. Nitrogen topdressing was carried out 30 days after seedling emergence at a dose of $100 \mathrm{~kg} \mathrm{ha}^{-1} \mathrm{~N}$ in the form of urea. In order to avoid the competition of invasive plants, manual weeding was carried out.

The different water regimes were obtained using a sprinkler irrigator bar $40 \mathrm{~m}$ wide, connected to a spool with adjustable speed. Irrigation was performed homogeneously for the first 30 days after emergence in order to establish growth of all plants, with a total applied depth of $126 \mathrm{~mm}$. After this period, the modified line source methodology was applied [14], using sprinklers with decreasing water flows from the central area to the end of the bar. The sprinklers were overlapped in order to promote a decreasing gradient of water from the central area to the edge of the bar.

Each water regime consisted of an experimental unit of $2.5 \mathrm{~m}^{2}$ in area within the plot (subplot), formed by 5 lines, with $0.5 \mathrm{~m}$ spacing. Over the stress treatment 10 irrigations were carried out, and the accumulated uniform irrigation plus the variable irrigations gave a total of 150,247, 389, and $480 \mathrm{~mm}$ for the 4 water regimes. The highest level of irrigation was determined as described in the irrigation monitoring program in the Cerrado [15], 
through replacement of evapotranspiration using agrometeorological indicators of the region, the soil type, the date of full emergence of plants, and wheat as a reference. Although our experiment was carried out with quinoa, we used wheat as a reference crop for irrigation, understanding that it has similar water consumption. Irrigation was carried out approximately every 5 days, according to the climatic conditions and crop phenological phase. To measure the water depth applied in each irrigation 2 rows of collectors parallel to the irrigation line were set up.

Thermal images were acquired using a thermal infrared camera (FLIR ${ }^{\circledR}$ T420, FLIR Systems, Wilsonville, OR, USA) with the following characteristics: thermal spatial resolution of $320 \times 240$ pixels, spectral response of 7.5 to $13 \mu \mathrm{m}$, thermal sensitivity of pixels from $0.045{ }^{\circ} \mathrm{C}$ to $30{ }^{\circ} \mathrm{C}$, and temperature accuracy of \pm 2 . The camera was mounted on an unmanned aerial vehicle (XFly, O X800, Bauru, SP, Brazil) at a height of $60 \mathrm{~m}$ from the canopy and the images were performed at the same time and day as the physiological variables. For the processing of images and to obtain temperature data in the canopies of quinoa plants, the QGIS software was used [16]. The RGB (red, green and blue) and thermal images were geo-referenced for the generation of an orthomosaic and later classified to select only the areas of plant canopies in the useful parcel, avoiding picking up exposed soil.

\subsection{Variables Analyzed \\ 2.3.1. Grain Analysis}

Quinoa grain productivity and productivity per unit of applied water (PUAA) were evaluated for all studied genotypes under 4 water regimes (WRs 150, 247, 389 and $480 \mathrm{~mm}$ ). The panicles were harvested by hand, and later placed in a Wintersteiger plot harvester. In each subplot an area of $2.5 \mathrm{~m}^{2}$ was harvested. Grain moisture was corrected to $13 \%$ and the results were analysed as ton $\mathrm{ha}^{-1}$. The productivity per unit of applied water (PUAA) was determined by the ratio between the grain yield and the amount of water applied during the whole crop cycle, analysed in $\mathrm{kg} \mathrm{ha}^{-1} \mathrm{~mm}^{-1}$. Productivity per unit of applied water (PUAA) was also evaluated, and calculated using the following equation:

$$
\text { PUAA }=\text { Prod } / \text { LTD }
$$

where

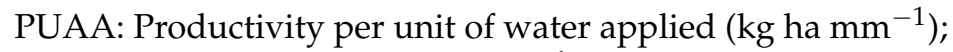

Prod: Grain productivity, in $\mathrm{kg} \mathrm{ha}^{-1}$; and

LTD: Total irrigation depth available referring to the amount of water applied during the crop cycle, in $\mathrm{mm}$.

The weight of 1000 grains was evaluated for 4 genotypes (CPAC4, CPAC11, CPAC19, and the early BRS Piabiru). The weight of 1000 grains was determined according to the method described by [17], in which 100 grains from each subplot are weighed using a semi-analytical balance and the result obtained is multiplied by 10 .

The functional quality of the grains was evaluated for all studied genotypes. Functional quality was evaluated by quantification of flavonoids and total anthocyanins and flavonoids [18]. The grains were ground; subsequently, $5 \mathrm{~g}$ was weighed and the anthocyanin and flavonoids from the grains were extracted with $30 \mathrm{~mL}$ of a solution of ethyl alcohol and $1.5 \mathrm{~N} \mathrm{HCl}$. After homogenization for $1 \mathrm{~min}$, the volume was made up to $50 \mathrm{~mL}$ in volumetric flasks. This mixture remained at $8^{\circ} \mathrm{C}$ for $16 \mathrm{~h}$. After filtration, absorbances (Abs) were taken at $535 \mathrm{~nm}$ for anthocyanin and $374 \mathrm{~nm}$ for flavonoids. The results were expressed in $\mathrm{mg} / 100 \mathrm{~g}$ of quinoa grains. The contents of flavonoids 9 factor 76.6) and of anthocyanins (factor 98.2) were calculated according to the formulas: Dilution Factor $(\mathrm{DF})=(100 \times$ volume $(\mathrm{mL})) /$ weight $(\mathrm{g}))$; Content of flavonoids/anthocyanins = $($ Abs $\times \mathrm{DF}) /$ factor. Results were expressed in $\mathrm{mg} / 100 \mathrm{~g}$ of quinoa grains. 


\subsubsection{Physiological Analysis}

During the flowering period of the crops, 60 days after emergence the following variables were evaluated: gas exchange (photosynthesis; stomatal conductance, internal $\mathrm{CO}_{2}$ concentration in the leaves, and transpiration), leaf chlorophyll ( $a, b$, total), chlorophyl fluorescence, proline content, relative water content, and plant height. These variables were analysed for 4 genotypes (CPAC4, CPAC11, CPAC19, and the early BRS Piabiru), with exception of plant height, which was analysed in all genotypes. Plant height was measured from the base of the stem to the peak of its inflorescence using a measuring tape. Five plants per subplot were evaluated.

Gas exchange was measured using an IRGA infrared gas analyzer model LI-6400XT (LI-COR, Inc., Lincoln, NE, USA) between 08:00 and 11:00 on the youngest fully expanded leaves. Ambient air temperature and relative humidity were used and the $\mathrm{CO}_{2}$ concentration in the chamber was maintained at $400 \mu \mathrm{mol} \mathrm{mol}^{-1}$ together with a saturating photosynthetically active photon flux density (PPFD) of $2000 \mu \mathrm{mol} \mathrm{m}^{-2} \mathrm{~s}^{-1}$. To determine light saturation, a PPFD curve of 0, 20, 60, 100, 250, 500, 1000, 2000, 2250, 2500, and $3000 \mu \mathrm{mol} \mathrm{m}^{-2} \mathrm{~s}^{-1}$ was obtained under ambient $\mathrm{CO}_{2}$. Maximum fluorescence $\left(\mathrm{F}^{\prime} \mathrm{m}\right)$ and basal fluorescence $\left(\mathrm{F}^{\prime} 0\right)$ were evaluated for light-adapted leaves using the portable open flow gas exchange system (IRGA-LI-6400XT; LI-COR Inc., Lincoln, NE, USA). The effective quantum yield of Photosystem II is given by, $\mathrm{F}^{\prime} \mathrm{v} / \mathrm{F}^{\prime} \mathrm{m}=\left(\mathrm{Fm}^{\prime}-\mathrm{F}^{\prime}\right) / \mathrm{Fm}^{\prime}$, according to [19].

The chlorophyll index $(a, b, a+b$ and $a / b)$ was evaluated in the morning with the aid of a digital ChlorofiLOG, model CFL 1030, from Falker in the youngest fully expanded leaves, and 10 readings were taken for each treatment.

The relative water content (RWC) was determined according to the methodology of [20], using leaf discs of $1 \mathrm{~cm}$ in diameter obtained from leaves collected predawn between 03:00 and 05:00. The discs were immediately weighed after collection to determine the fresh mass (FM). The turgid mass (TM) of the leaf discs was obtained by hydration in distilled water for $24 \mathrm{~h}$ and the dry mass (DM) was obtained after drying in a forced air oven at $60^{\circ} \mathrm{C}$. The RWC was calculated according to the formula.

$$
\mathrm{RWC}=((\mathrm{FM}-\mathrm{DM}) /(\mathrm{TM}-\mathrm{DM})) \times 100 \%,
$$

The proline content was determined according to [21]. Completely expanded young leaves were collected between 13:30 and 15:00. Samples were extracted by grinding $0.5 \mathrm{~g}$ of fresh leaf material in $10 \mathrm{~mL}$ of $3 \%$ sulfosalicylic acid. Then, $500 \mu \mathrm{L}$ of the extract of each sample was placed in a test tube containing $2.75 \mathrm{~mL}$ of distilled water, with the addition of $2 \mathrm{~mL}$ of acid ninhydrin, $2 \mathrm{~mL}$ of glacial acetic acid, and 100 microliters of glycine $(126 \mathrm{mM})$. Acid ninhydrin was prepared by warming $1.25 \mathrm{~g}$ in $30 \mathrm{~mL}$ glacial acetic acid and $20 \mathrm{~mL}$ $6 \mathrm{M}$ phosphoric acid. Then, the samples were kept for $1 \mathrm{~h}$ in a water bath at $100{ }^{\circ} \mathrm{C}$ [21]. After cooling the samples by immersion in an ice bath the optical density was evaluated at $515 \mathrm{~nm}$ using a Pharmacia Ultrospect III spectrophotometer. The absorbance obtained was compared with the standard proline curve and the results expressed as $\mu \mathrm{mol}$ of proline $/ \mathrm{g}$ of fresh mass (FM).

\subsection{Statistical Analysis}

Data were subjected to analysis of variance at $5 \%$ probability by the $\mathrm{F}$ test and the comparison of means was carried out using the Scott-Knott test and Tukey's test. The statistical model was adjusted using the Proc Mixed from SAS [22] using the restricted maximum likelihood method. For non-significant interactions, factors were analysed separately (genotype and water regime). Figures were produced using the software Sigma Plot, version 10 [23].

\section{Results}

\subsection{Productivity}

In general, the genotypes responded differently to water regimes, reinforcing the idea that the productive potential, productivity per unit of applied water (PUAA), and 
responsiveness to irrigation depend on the genotype (Tables 1 and 2). We found a significant interaction between quinoa genotypes and WRs for productivity (Table 1). For most quinoa genotypes, the yield was reduced with WR 247, with exception of CPAC3, CPAC8, CPAC9, CPAC14, and CPAC19 which had reduced yield with WR $389 \mathrm{~mm}$.

Table 1. Productivity ( $\mathrm{t} \mathrm{ha}^{-1}$ ) of 18 quinoa genotypes and BRS Piabiru under 4 water regimes.

\begin{tabular}{ccccc}
\hline \multirow{2}{*}{ Genotypes } & \multicolumn{4}{c}{ Water Regime $\mathbf{( m m )}$} \\
\cline { 2 - 5 } & $\mathbf{4 8 0}$ & $\mathbf{3 8 9}$ & $\mathbf{2 4 7}$ & $\mathbf{1 5 0}$ \\
\hline CPAC1 & $7.82 \mathrm{aA}$ & $8.34 \mathrm{bA}$ & $4.06 \mathrm{bB}$ & $1.56 \mathrm{bC}$ \\
CPAC2 & $8.32 \mathrm{aA}$ & $7.89 \mathrm{bA}$ & $3.94 \mathrm{cB}$ & $1.83 \mathrm{bC}$ \\
CPAC3 & $8.02 \mathrm{aA}$ & $7.81 \mathrm{bB}$ & $6.25 \mathrm{aC}$ & $1.94 \mathrm{bD}$ \\
CPAC4 & $8.40 \mathrm{aA}$ & $8.23 \mathrm{bA}$ & $5.21 \mathrm{aB}$ & $1.95 \mathrm{bC}$ \\
CPAC5 & $8.17 \mathrm{aA}$ & $7.90 \mathrm{bA}$ & $5.22 \mathrm{aB}$ & $1.94 \mathrm{bC}$ \\
CPAC6 & $8.50 \mathrm{aA}$ & $8.84 \mathrm{aA}$ & $5.68 \mathrm{aB}$ & $2.46 \mathrm{aC}$ \\
CPAC8 & $8.64 \mathrm{aA}$ & $7.07 \mathrm{cB}$ & $4.50 \mathrm{aC}$ & $1.58 \mathrm{bD}$ \\
CPAC9 & $8.21 \mathrm{aA}$ & $7.01 \mathrm{cB}$ & $5.75 \mathrm{aC}$ & $2.11 \mathrm{bD}$ \\
CPAC10 & $8.56 \mathrm{aA}$ & $8.36 \mathrm{bA}$ & $5.12 \mathrm{aB}$ & $2.61 \mathrm{aC}$ \\
CPAC11 & $5.66 \mathrm{bB}$ & $6.80 \mathrm{cA}$ & $5.40 \mathrm{aB}$ & $2.38 \mathrm{aC}$ \\
CPAC12 & $8.57 \mathrm{aA}$ & $7.83 \mathrm{bA}$ & $5.82 \mathrm{aB}$ & $2.58 \mathrm{aC}$ \\
CPAC13 & $8.85 \mathrm{aA}$ & $9.73 \mathrm{aA}$ & $4.17 \mathrm{bB}$ & $2.60 \mathrm{aC}$ \\
CPAC14 & $9.21 \mathrm{aA}$ & $6.51 \mathrm{cB}$ & $3.88 \mathrm{bB}$ & $1.61 \mathrm{bB}$ \\
BRS Piabiru & $7.58 \mathrm{aA}$ & $8.14 \mathrm{bA}$ & $5.40 \mathrm{aB}$ & $1.84 \mathrm{bC}$ \\
CPAC16 & $8.51 \mathrm{aA}$ & $7.46 \mathrm{cA}$ & $4.74 \mathrm{aB}$ & $2.33 \mathrm{aC}$ \\
CPAC17 & $8.92 \mathrm{aA}$ & $8.44 \mathrm{bA}$ & $4.80 \mathrm{aB}$ & $3.64 \mathrm{aC}$ \\
CPAC18 & $8.96 \mathrm{Aa}$ & $9.16 \mathrm{aA}$ & $4.75 \mathrm{aB}$ & $2.21 \mathrm{bC}$ \\
CPAC19 & $7.71 \mathrm{aA}$ & $6.42 \mathrm{cB}$ & $2.53 \mathrm{cC}$ & $1.79 \mathrm{bC}$ \\
CPAC20 & $7.97 \mathrm{aA}$ & $7.08 \mathrm{cA}$ & $3.93 \mathrm{bB}$ & $2.09 \mathrm{bC}$
\end{tabular}

Means followed by the same lowercase letter (column) or uppercase letter (line), do not differ according to the Scott-Knott test at a $5 \%$ probability.

Table 2. Productivity per unit of applied water $\left(\mathrm{kg} \mathrm{ha}^{-1} \mathrm{~mm}^{-1}\right)$ of 18 quinoa genotypes and BRS Piabiru under 4 water regimes.

\begin{tabular}{ccccc}
\hline \multirow{2}{*}{ Genotypes } & \multicolumn{4}{c}{ Water Regime $(\mathbf{m m})$} \\
\cline { 2 - 5 } & $\mathbf{4 8 0}$ & $\mathbf{3 8 9}$ & $\mathbf{2 4 7}$ & $\mathbf{1 5 0}$ \\
\hline CPAC1 & $17.18 \mathrm{aB}$ & $22.2 \mathrm{aA}$ & $16.43 \mathrm{cB}$ & $10.41 \mathrm{cC}$ \\
CPAC2 & $15.89 \mathrm{aB}$ & $21.0 \mathrm{aA}$ & $13.02 \mathrm{~dB}$ & $13.0 \mathrm{cB}$ \\
CPAC3 & $18.59 \mathrm{aB}$ & $20.8 \mathrm{aB}$ & $25.29 \mathrm{aA}$ & $13.5 \mathrm{cD}$ \\
CPAC4 & $16.89 \mathrm{aB}$ & $21.15 \mathrm{aA}$ & $21.1 \mathrm{bA}$ & $13.03 \mathrm{cC}$ \\
CPAC5 & $16.9 \mathrm{aB}$ & $21.0 \mathrm{aA}$ & $23.9 \mathrm{bA}$ & $12.1 \mathrm{cC}$ \\
CPAC6 & $17.7 \mathrm{aB}$ & $22.72 \mathrm{aA}$ & $23.0 \mathrm{aA}$ & $16.4 \mathrm{bB}$ \\
CPAC8 & $18.01 \mathrm{aA}$ & $18.18 \mathrm{bA}$ & $18.23 \mathrm{cA}$ & $10.52 \mathrm{bB}$ \\
CPAC9 & $17.73 \mathrm{aB}$ & $18.01 \mathrm{bB}$ & $23.3 \mathrm{aA}$ & $14.10 \mathrm{cC}$ \\
CPAC10 & $17.83 \mathrm{aB}$ & $21.49 \mathrm{aA}$ & $20.6 \mathrm{bA}$ & $15.38 \mathrm{cB}$ \\
CPAC11 & $11.1 \mathrm{bC}$ & $18.0 \mathrm{bB}$ & $21.89 \mathrm{bA}$ & $15.85 \mathrm{bA}$ \\
CPAC12 & $18.0 \mathrm{aB}$ & $20.1 \mathrm{aB}$ & $23.56 \mathrm{aA}$ & $17.24 \mathrm{bD}$ \\
CPAC13 & $19.83 \mathrm{aB}$ & $25.9 \mathrm{aA}$ & $19.1 \mathrm{bB}$ & $17.6 \mathrm{bB}$ \\
CPAC14 & $12.69 \mathrm{aB} 0$ & $16.3 \mathrm{bA}$ & $15.71 \mathrm{cA}$ & $10.1 \mathrm{cC}$ \\
BRS Piabiru & $15.79 \mathrm{aB}$ & $20.92 \mathrm{aA}$ & $21.88 \mathrm{bA}$ & $14.37 \mathrm{cB}$ \\
CPAC16 & $17.74 \mathrm{aA}$ & $19.8 \mathrm{bA}$ & $19.18 \mathrm{bA}$ & $15.57 \mathrm{bA}$ \\
CPAC17 & $18.58 \mathrm{aB}$ & $21.70 \mathrm{aA}$ & $19.44 \mathrm{bB}$ & $24.25 \mathrm{aA}$ \\
CPAC18 & $18.66 \mathrm{aB}$ & $23.56 \mathrm{aA}$ & $16.89 \mathrm{cB}$ & $14.71 \mathrm{cC}$ \\
CPAC19 & $16.08 \mathrm{aA}$ & $16.50 \mathrm{bA}$ & $11.6 \mathrm{~dB}$ & $10.25 \mathrm{cB}$ \\
CPAC20 & $17.82 \mathrm{aA}$ & $18.82 \mathrm{bA}$ & $15.94 \mathrm{cA}$ & $11.89 \mathrm{cB}$
\end{tabular}

Means followed by the same lowercase letter (column) or uppercase letter (line) do not differ according to the Scott-Knott test at a $5 \%$ probability.

Under the highest WR $(480 \mathrm{~mm})$ all genotypes obtained similarly high yields, meaning that the genotypes could not be distinguished. The only exception was CPAC11 (a dwarf 
genotype), which presented significantly lower productivity (Table 1) and the lowest PUAA (Table 2). However, in the intermediate WR $(389 \mathrm{~mm})$, there were major differences among genotypes, with the genotypes CPAC6, CPAC13, and CPAC18 standing out as having the highest productivity (Table 1). Under the water deficit regimes there was a clearer distinction between the genotypes, which were divided into three groups: high, medium, and low productivity. Under the $247 \mathrm{~mm} \mathrm{WR}$, with a reduction of $49 \%$ in applied water, the genotypes presented a high productivity of between 2.53 and $6.26 \mathrm{t} \mathrm{ha}^{-1}$. On the other hand, under the extremely low water regime $(150 \mathrm{~mm})$, the genotypes CPAC6, CPAC10, CPAC11, CPAC12, CPAC13, CPAC16, and CPAC17 were more productive. The genotypes CPAC3, CPAC 8, CPAC9, CPAC14, and CPAC19 were more sensitive to mild water deficit (WR 389), showing reduced productivity under this water regime, whilst CPA11 showed the opposite response, with increased productivity with $91 \mathrm{~mm}$ less water applied (Table 1).

\subsection{Productivity Per Unit of Applied Water (PUAA)}

In general, the lowest PUAA was found for WR 480, with only the genotypes CPAC8, CPAC16, CPAC19, and CPAC20 presenting similar PUAA at $480 \mathrm{~mm}$ and under deficit conditions (380 and $247 \mathrm{~mm}$, Table 2). The highest PUAA occurred between 247 and $389 \mathrm{~mm}$ WR for most quinoa genotypes (Table 2). Comparing WR $480 \mathrm{~mm}$ with the intermediate $389 \mathrm{~mm}$ and $247 \mathrm{~mm}$ WRs, there was a reduction of 36 and $49 \%$ in volume of total water applied and an increase by 23 and $21 \%$ in PUAA, respectively (Table 2). The genotypes with the highest PUAA in $247 \mathrm{~mm}$ were CPAC3, CPAC6, CPAC9, and CPAC12, and with the exception of CPAC6, the other genotypes had low PUAA in the other WRs (Table 2).

Under the low water regime of $150 \mathrm{~mm}$ the PUAA for CPAC17 was significantly higher than the other genotypes, and importantly, this variable was similar under intermediate and low water regimes, meaning that regardless of the water regime its PUAA did not alter. Although CPAC17 had the highest productivity under WR $150 \mathrm{~mm}\left(3.64\right.$ ton ha $\left.{ }^{-1}\right)$ compared to all studied genotypes (Table 1), it had greater productivity under intermediate (8.44 ton ha $\left.{ }^{-1}\right)$ and high $\left(8.92\right.$ ton ha $\left.{ }^{-1}\right)$ WRs. Under the lowest WR $(128 \mathrm{~mm})$, however, overall efficiency was very low as the stress was very high.

\subsection{Thousand Grain Weight}

The weight of 1000 grains (TGW) of quinoa was evaluated, and there was no significant interaction between the factors. The effect of the water regimes on TGW is shown in Figure S1A), where there is an increase in TGW up to WR $389 \mathrm{~mm}$ and from this level, there was no increase in grain weight with the increase in water availability. The CPAC11 and early Piabiru genotypes showed better results, and CPAC19 had lower grain weights compared to other genotypes. In this study, a TGW of 2.35 to 2.84 was obtained, depending on the genotype (Figure S1B).

\subsection{Functional Quality}

Our study shows a significant interaction between quinoa genotypes and water regimes and the abundance of flavonoids (Table 3) and total anthocyanins (Table 4). For flavonoid contents, BRS Piabiru and CPAC2 did not respond to all WRs, but showed lower values than CPAC9, which was influenced by WRs. For anthocyanin contents, CPAC1, CPAC11, CPAC16, CPAC18, CPAC19, and CPAC20 presented similar values in all WRs, and these genotypes had lower values than CPAC9. 
Table 3. Total flavonoid concentrations (mg/100 g) in grains of 18 quinoa genotypes and BRS Piabiru under 4 water regimes.

\begin{tabular}{lcccc}
\hline \multirow{2}{*}{ Genotypes } & \multicolumn{4}{c}{ Water Regime $\mathbf{( m m )}$} \\
\cline { 2 - 5 } & $\mathbf{4 8 0}$ & $\mathbf{3 8 9}$ & $\mathbf{2 4 7}$ & $\mathbf{1 5 0}$ \\
\hline CPAC1 & $81.59 \mathrm{cB}$ & $101.62 \mathrm{dA}$ & $66.21 \mathrm{dC}$ & $88.34 \mathrm{dA}$ \\
CPAC2 & $95.97 \mathrm{bA}$ & $97.23 \mathrm{dA}$ & $85.71 \mathrm{dA}$ & $92.21 \mathrm{dA}$ \\
CPAC3 & $98.83 \mathrm{bA}$ & $51.54 \mathrm{eB}$ & $97.12 \mathrm{cA}$ & $113.25 \mathrm{cA}$ \\
CPAC4 & $80.02 \mathrm{cB}$ & $98.31 \mathrm{dA}$ & $91.64 \mathrm{cA}$ & $96.23 \mathrm{dA}$ \\
CPAC5 & $84.07 \mathrm{cB}$ & $103.0 \mathrm{dA}$ & $74.58 \mathrm{~dB}$ & $86.80 \mathrm{~dB}$ \\
CPAC6 & $83.65 \mathrm{cC}$ & $115.23 \mathrm{cA}$ & $82.81 \mathrm{dC}$ & $100.05 \mathrm{~dB}$ \\
CPAC8 & $96.95 \mathrm{bB}$ & $110.72 \mathrm{dA}$ & $114.25 \mathrm{bA}$ & $93.58 \mathrm{~dB}$ \\
CPAC9 & $215.22 \mathrm{aB}$ & $171.32 \mathrm{aC}$ & $205.11 \mathrm{aB}$ & $226.02 \mathrm{aA}$ \\
CPAC10 & $85.48 \mathrm{cC}$ & $110.0 \mathrm{~dB}$ & $96.32 \mathrm{cC}$ & $210.81 \mathrm{bA}$ \\
CPAC11 & $89.00 \mathrm{cB}$ & $118.59 \mathrm{cA}$ & $100.97 \mathrm{cB}$ & $113.25 \mathrm{cA}$ \\
CPAC12 & $96.17 \mathrm{bB}$ & $120.98 \mathrm{cA}$ & $84.82 \mathrm{~dB}$ & $112.51 \mathrm{cA}$ \\
CPAC13 & $99.47 \mathrm{bA}$ & $111.33 \mathrm{dA}$ & $84.73 \mathrm{~dB}$ & $102.33 \mathrm{dA}$ \\
CPAC14 & $115.19 \mathrm{bA}$ & $119.74 \mathrm{cA}$ & $84.94 \mathrm{~dB}$ & $104.71 \mathrm{cA}$ \\
BRS Piabiru & $104.15 \mathrm{bA}$ & $105.89 \mathrm{dA}$ & $101.98 \mathrm{cA}$ & $104.56 \mathrm{cA}$ \\
CPAC16 & $105.09 \mathrm{bB}$ & $124.80 \mathrm{cA}$ & $99.48 \mathrm{cB}$ & $110.93 \mathrm{cB}$ \\
CPAC17 & $115.73 \mathrm{bC}$ & $145.76 \mathrm{bA}$ & $97.05 \mathrm{cC}$ & $118.86 \mathrm{cB}$ \\
CPAC18 & $88.27 \mathrm{cB}$ & $62.76 \mathrm{eC}$ & $94.25 \mathrm{cB}$ & $113.57 \mathrm{cA}$ \\
CPAC19 & $109.63 \mathrm{bB}$ & $119.74 \mathrm{cA}$ & $102.59 \mathrm{cB}$ & $100.01 \mathrm{~dB}$ \\
CPAC20 & $119.93 \mathrm{bB}$ & $139.03 \mathrm{bA}$ & $114.40 \mathrm{bB}$ & $115.41 \mathrm{cB}$
\end{tabular}

Means followed by the same lowercase letter (column) or uppercase letter (line) do not differ according to the Scott-Knott test at a 5\% probability.

Table 4. Total anthocyanin concentrations $(\mathrm{mg} / 100 \mathrm{~g})$ in grains of 18 quinoa genotypes and BRS Piabiru under 4 water regimes.

\begin{tabular}{ccccc}
\hline \multirow{2}{*}{ Genotypes } & \multicolumn{4}{c}{ Water Regime $\mathbf{( m m )}$} \\
\cline { 2 - 5 } & $\mathbf{4 8 0}$ & $\mathbf{3 8 9}$ & $\mathbf{2 4 7}$ & $\mathbf{1 5 0}$ \\
\hline CPAC1 & $0.80 \mathrm{cA}$ & $0.76 \mathrm{dA}$ & $0.76 \mathrm{cA}$ & $0.80 \mathrm{dA}$ \\
CPAC2 & $0.63 \mathrm{dA}$ & $0.68 \mathrm{dA}$ & $0.62 \mathrm{dA}$ & $0.40 \mathrm{cB}$ \\
CPAC3 & $0.63 \mathrm{dD}$ & $1.0 \mathrm{bB}$ & $0.83 \mathrm{cC}$ & $1.16 \mathrm{cA}$ \\
CPAC4 & $0.59 \mathrm{~dB}$ & $0.65 \mathrm{eB}$ & $0.59 \mathrm{~dB}$ & $0.76 \mathrm{dA}$ \\
CPAC5 & $0.74 \mathrm{cA}$ & $0.59 \mathrm{eB}$ & $0.54 \mathrm{~dB}$ & $0.70 \mathrm{dA}$ \\
CPAC6 & $0.60 \mathrm{~dB}$ & $0.73 \mathrm{dA}$ & $0.65 \mathrm{~dB}$ & $0.84 \mathrm{dA}$ \\
CPAC8 & $0.58 \mathrm{~dB}$ & $1.07 \mathrm{bA}$ & $0.55 \mathrm{~dB}$ & $0.57 \mathrm{eB}$ \\
CPAC9 & $1.72 \mathrm{aC}$ & $1.89 \mathrm{aB}$ & $1.44 \mathrm{aD}$ & $2.05 \mathrm{aA}$ \\
CPAC10 & $1.16 \mathrm{bA}$ & $0.73 \mathrm{~dB}$ & $0.76 \mathrm{cB}$ & $0.91 \mathrm{~dB}$ \\
CPAC11 & $0.61 \mathrm{dA}$ & $0.48 \mathrm{fA}$ & $0.54 \mathrm{dA}$ & $0.61 \mathrm{eA}$ \\
CPAC12 & $0.55 \mathrm{~dB}$ & $0.68 \mathrm{dA}$ & $0.50 \mathrm{~dB}$ & $0.65 \mathrm{eB}$ \\
CPAC13 & $0.66 \mathrm{~dB}$ & $0.63 \mathrm{eB}$ & $0.50 \mathrm{dC}$ & $0.73 \mathrm{dA}$ \\
CPAC14 & $0.83 \mathrm{cB}$ & $0.82 \mathrm{cB}$ & $0.68 \mathrm{cC}$ & $0.94 \mathrm{cA}$ \\
BRS Piabiru & $0.89 \mathrm{cB}$ & $1.08 \mathrm{bA}$ & $0.61 \mathrm{dD}$ & $0.74 \mathrm{dC}$ \\
CPAC16 & $0.72 \mathrm{cA}$ & $0.65 \mathrm{eA}$ & $0.81 \mathrm{cA}$ & $0.80 \mathrm{dA}$ \\
CPAC17 & $1.03 \mathrm{bB}$ & $0.86 \mathrm{cC}$ & $0.79 \mathrm{cC}$ & $1.18 \mathrm{bA}$ \\
CPAC18 & $0.68 \mathrm{dA}$ & $0.61 \mathrm{eA}$ & $0.72 \mathrm{cA}$ & $0.60 \mathrm{eA}$ \\
CPAC19 & $0.64 \mathrm{dA}$ & $0.63 \mathrm{eA}$ & $0.71 \mathrm{cA}$ & $0.66 \mathrm{eA}$ \\
CPAC20 & $1.13 \mathrm{bA}$ & $0.99 \mathrm{bA}$ & $1.06 \mathrm{bA}$ & $1.05 \mathrm{cA}$
\end{tabular}

Means followed by the same lowercase letter (column) or uppercase letter (line) do not differ according to the Scott-Knott test at $5 \%$ probability.

The accumulation of flavonoids in CPAC9 was greater than in BRS Piabiru and all other genotypes in all water regimes, reaching approximately double the concentration of flavonoids in most genotypes in both higher and lower water regimes (Table 3).

Similar to that observed for flavonoid accumulation, CPAC9 also accumulated higher anthocyanin content and had greater concentrations than BRS Piabiru and other geno- 
types under all water regimes, accumulating approximately double the concentration of anthocyanins (Table 4). In addition, CPAC9 was among the genotypes with the highest productivity under both high $\left(8.21\right.$ ton $\left.\mathrm{ha}^{-1}\right)$ and intermediate $\left(7.01\right.$ ton ha $\left.{ }^{-1}\right)$ WRs (Table 1).

\subsection{Plant Height}

Figure 2A shows quinoa plant height in response to water regimes. In the higher water regimes (389 and $480 \mathrm{~mm}$ ), the plants presented greater heights $(1.50$ and $1.51 \mathrm{~m})$ than the intermediate $(247 \mathrm{~mm})$ and low $(150 \mathrm{~mm})$ water regimes, which presented plants with lower heights of 1.40 and $1.17 \mathrm{~m}$, respectively (Figure 2B). Severe water deficit $(128 \mathrm{~mm}$ ) reduced plant height by $22 \%$. Comparing among genotypes, genotype CPAC 11 was significantly shorter than all others, with an average height of $0.94 \mathrm{~m}$ (Figure 2B).
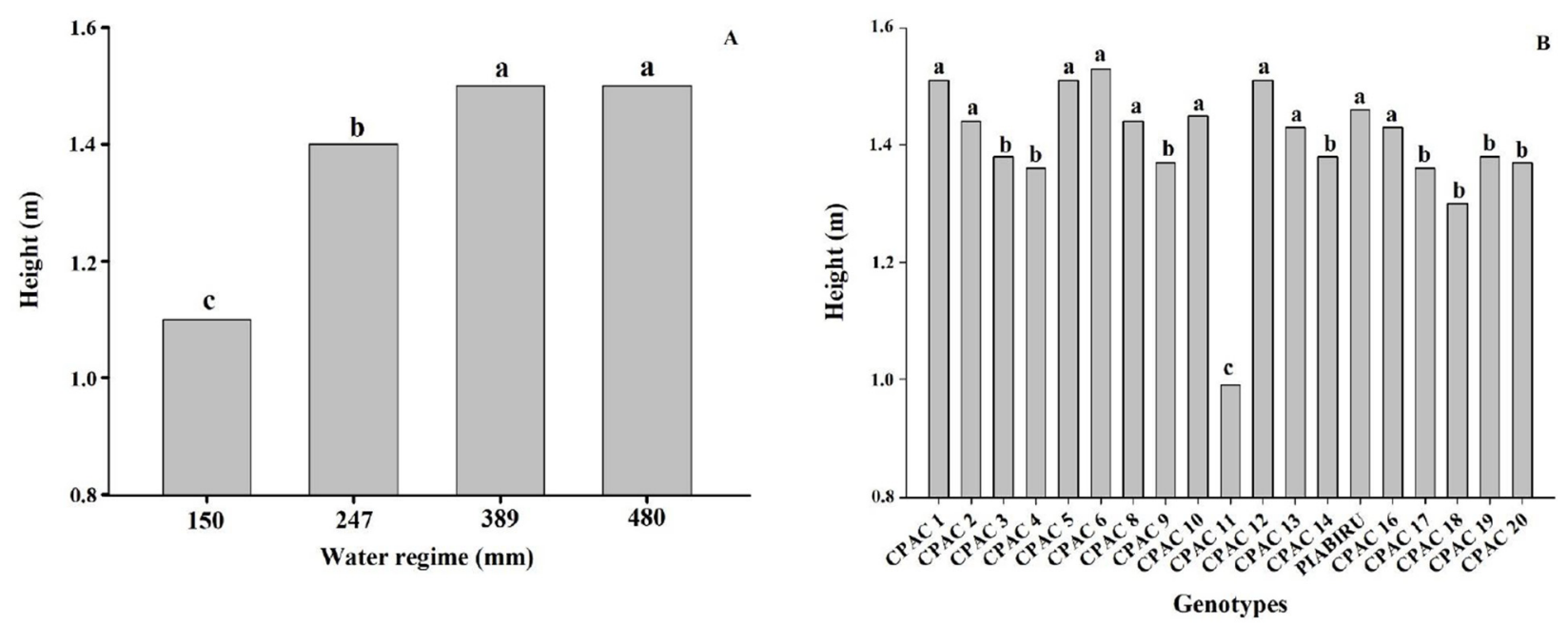

Figure 2. Height of different quinoa genotypes under 4 water regimes. (A) Effect of 4 water regimes in plant height in 20 quinoa genotypes. (B) Means followed by the same lowercase letter do not differ according to the Scott-Knott test at 5\% probability.

\subsection{Canopy Temperature}

For the leaf temperature variable, no interaction between the factors was obtained and no significant difference was observed between the genotypes. Thus, the effect of water regimes on the temperature of the plants was subjected to regression analysis. This analysis showed a significant relationship between water availability and leaf temperature $(p<0.05)$, with the maximum temperature value $\left(35.1^{\circ} \mathrm{C}\right)$ for the lowest WR $(150 \mathrm{~mm})$ and the minimum $\left(25.5^{\circ} \mathrm{C}\right)$ in WR $480 \mathrm{~mm}$ (Figure S2), demonstrating that under severe drought the canopy of quinoa genotypes showed an increase in temperature of $9.6^{\circ} \mathrm{C}$.

\subsection{Leaf Gas Exchange}

The stomatal conductance and transpiration, as expected, were higher in the highwater regime and decreased as water restriction occurred, with a reduction of $94,88,92$, and $91 \%$ for the genotypes CPAC4, CPAC11, and CPAC19 and the BRS Piabiru precoce, respectively (Table 5). The different water conditions affected the four analysed genotypes differently, and CPAC9 had the highest stomatal conductance in the intermediate WR $(247 \mathrm{~mm})$, which represents off-season conditions. The CPAC11 genotype was more efficient in maintaining stomatal conductance and transpiration, as it had lower values in the high water regimes but little decrease in the intermediate WR (Table 5). 
Table 5. Stomatal conductance $\left(g_{s}-\mathrm{mol} \mathrm{m}^{-2} \mathrm{~s}^{-1}\right)$, transpiration rate $\left(E-\mathrm{mmol} \mathrm{m}^{-2} \mathrm{~s}^{-1}\right.$ Internal carbon $\left(C_{i}-\mu \mathrm{mol} \mathrm{m}{ }^{-2} \mathrm{~s}^{-1}\right)$, and photosynthetic rate $\left(A-\mu \mathrm{mol} \mathrm{m}{ }^{-2} \mathrm{~s}^{-1}\right)$ of 4 quinoa genotypes (CPAC4, CPAC9, CPAC11, and Piabiru), under 4 water regimes (150, 247, 389, $480 \mathrm{~mm})$.

\begin{tabular}{cccccc}
\hline \multirow{2}{*}{ Genotypes } & \multicolumn{4}{c}{ Water Regime (mm) } \\
\cline { 3 - 6 } & & $\mathbf{1 5 0}$ & $\mathbf{2 4 7}$ & $\mathbf{3 8 9}$ & $\mathbf{4 8 0}$ \\
\cline { 3 - 6 } $\boldsymbol{*} \boldsymbol{s}$ & CPAC4 & $0.034 \mathrm{cD}$ & $0.235 \mathrm{bC}$ & $0.470 \mathrm{bB}$ & $0.583 \mathrm{bA}$ \\
& CPAC11 & $0.040 \mathrm{cC}$ & $0.232 \mathrm{bB}$ & $0.358 \mathrm{cA}$ & $0.342 \mathrm{cA}$ \\
& BRS Piabiru & $0.058 \mathrm{aD}$ & $0.218 \mathrm{bC}$ & $0.516 \mathrm{abB}$ & $0.629 \mathrm{aA}$ \\
& CPAC19 & $0.050 \mathrm{bC}$ & $0.329 \mathrm{aB}$ & $0.552 \mathrm{aA}$ & $0.594 \mathrm{abA}$ \\
\hline \multirow{5}{*}{$\boldsymbol{E}$} & CPAC4 & $1.45 \mathrm{bcD}$ & $6.15 \mathrm{aC}$ & $8.96 \mathrm{aB}$ & $9.88 \mathrm{aA}$ \\
& CPAC11 & $1.20 \mathrm{cD}$ & $4.87 \mathrm{bC}$ & $6.43 \mathrm{cA}$ & $5.67 \mathrm{cB}$ \\
& BRS Piabiru & $3.11 \mathrm{aD}$ & $4.76 \mathrm{bC}$ & $8.20 \mathrm{aB}$ & $9.46 \mathrm{aA}$ \\
& CPAC19 & $1.71 \mathrm{bD}$ & $5.83 \mathrm{aC}$ & $7.27 \mathrm{bB}$ & $8.38 \mathrm{bA}$ \\
\hline \multirow{4}{*}{$\boldsymbol{i}$} & CPAC 4 & $144.0 \mathrm{aC}$ & $195.3 \mathrm{aB}$ & $239.9 \mathrm{bA}$ & $241.2 \mathrm{bA}$ \\
& CPAC11 & $112.6 \mathrm{bC}$ & $198.6 \mathrm{aB}$ & $253.6 \mathrm{aA}$ & $259.2 \mathrm{aA}$ \\
& BRS Piabiru & $129.0 \mathrm{abD}$ & $191.3 \mathrm{aC}$ & $257.0 \mathrm{aB}$ & $270.3 \mathrm{aA}$ \\
& CPAC19 & $82.5 \mathrm{cC}$ & $198.4 \mathrm{aB}$ & $255.9 \mathrm{aA}$ & $256.9 \mathrm{abA}$ \\
\hline \multirow{2}{*}{$\boldsymbol{A}$} & CPAC4 & $4.9 \mathrm{cD}$ & $19.0 \mathrm{cC}$ & $22.0 \mathrm{bB}$ & $28.1 \mathrm{bA}$ \\
& CPAC11 & $5.9 \mathrm{bC}$ & $20.5 \mathrm{bcB}$ & $22.9 \mathrm{bA}$ & $20.0 \mathrm{cB}$ \\
& BRS Piabiru & $9.0 \mathrm{aD}$ & $22.4 \mathrm{bC}$ & $32.9 \mathrm{aB}$ & $35.4 \mathrm{aA}$ \\
& CPAC19 & $8.9 \mathrm{aC}$ & $27.0 \mathrm{aB}$ & $32.9 \mathrm{aA}$ & $34.3 \mathrm{aA}$ \\
\hline
\end{tabular}

Means followed by the same lowercase letter (column) or uppercase letter (line) do not differ according to the Tukey test at a $5 \%$ probability.

We detected increased internal carbon (Ci) under the high water regimes and decreased $\mathrm{Ci}$ under severe stress, which agrees with the stomatal conductance and transpiration data as the absorption of $\mathrm{CO}_{2}$ is directly related to the degree of stomatal opening. (Table 5). Similarly, photosynthesis of the four genotypes decreased gradually with reduced water availability. In the comparison between the highest $(480 \mathrm{~mm})$ and the lowest $(150 \mathrm{~mm}) \mathrm{WR}$, reductions in photosynthetic rates of $83,70,74$, and $75 \%$ were observed for the genotypes CPAC4, CPAC11, CPAC19, and BRS Piabiru precoce, respectively. An interesting pattern was observed for net photosynthesis, as under the high WR there were two groups of genotypes. CPAC19 and the BRS Piabiru obtained high values whilst CPAC4 and CPAC11 obtained lower values; however, their values were similar under intermediate WR and then suffered a drastic reduction in the severe WR. Ci proved to be the least sensitive parameter and could only distinguish the genotypes under the most severe water stress regime (WR 150).

\subsection{Effective Quantum Yield of Photosystem II and Chlorophyll Index}

For the $\mathrm{F}^{\prime} \mathrm{v} / \mathrm{F}^{\prime} \mathrm{m}$ ratio, the factors varied independently, and no significant difference was observed between the genotypes. The effect of water regimes on the $\mathrm{F}^{\prime} \mathrm{v} / \mathrm{F}^{\prime} \mathrm{m}$ ratio of quinoa plants was therefore analysed using regression. This analysis indicated a significant relationship between water availability and $\mathrm{F}^{\prime} \mathrm{v} / \mathrm{F}^{\prime} \mathrm{m}(p<0.05)$, with a maximum value (0.52) of $\mathrm{F}^{\prime} \mathrm{v} / \mathrm{F}^{\prime} \mathrm{m}$ in the highest WR $(480 \mathrm{~mm})$ and the minimum $(0.43)$ in WR $150 \mathrm{~mm}$ (Figure S3), indicating that the efficiency of PSII was significantly reduced when the plants were submitted to the severe stress of WR $150 \mathrm{~mm}$. In contrast, chlorophyll index was not affected by the water regimes, but there were differences between the genotypes, with CPAC19 having the greatest total chlorophyll index and CPAC11 the lowest principally due to differences in chlorophyll a. CPAC19 also stood our as having the lowest chlorophyll a to $\mathrm{b}$ ratio (Supplemental Table S1).

\subsection{Leaf Proline and Relative Water Content}

There was a significant interaction between the quinoa genotypes and the water regimes for leaf proline content (Table S2). However, in general, proline concentrations 
were relatively insensitive to water restriction, as concentrations only increased under severe stress (Table S2). We detected no effects of genotype on leaf relative water content (RWC). Regression analysis revealed a significant relationship between water regime and RWC and a maximal RWC of $81 \%$ at WR $480 \mathrm{~mm}$ and minimal RWC of $58 \%$ at WR $150 \mathrm{~mm}$ (Figure S4). The 19\% reduction in water application of the WR $389 \mathrm{~mm}$ resulted in a minimal reduction in RWC (Figure S4).

\section{Discussion}

\subsection{Productivity and Productivity Per Unit of Applied Water (PUAA)}

Irrigation water use efficiency refers to the yield obtained per unit of applied water [24] and is a fundamental physiological parameter that indicates the ability of crops to conserve water in a region under water stress due to drought resistance and high potential productivity [25]. In our study, the low WR of $150 \mathrm{~mm}$ resulted in lower PUAA because under severe water restriction the quinoa genotypes cannot express their productive potential, whilst at high WRs (above $480 \mathrm{~mm}$ ) plants also had a lower PUAA due to an inability to absorb all supplied water and potentially an intolerance to excess water (Table 2). Under the high WR, genotypes showed high productivity; however, the grain dry matter per unit of applied water was low, indicating that there was no consistent relationship between crop yield and PUAA for this WR (Tables 1 and 2). Thus, the $389 \mathrm{~mm}$ and $247 \mathrm{~mm}$ WRs showed the highest PUAA, but the highest productivity was observed under the WR $480 \mathrm{~mm}$ and $389 \mathrm{~mm}$. Thus, WR $389 \mathrm{~mm}$ can be indicated for cultivating quinoa under an irrigated system in the Cerrado, as there is a trade-off in the relationship between productivity and water saving.

Quinoa plants can control the relationship between photosynthetic rate and transpiration, even with low leaf water potentials [26], and by limiting transpiration and inducing stomatal closure, they can increase PUAA and influence productivity under water stress [27]. In our study, with a $49 \%$ reduction in water applied throughout the crop cycle there was a $42 \%$ average yield loss over all genotypes (Table 1), indicating both drought tolerance and efficient water use, as this grain yield was obtained using half the water normally needed to meet the demands of the crop. Quinoa seeds can be obtained when little water is available in the vegetative stage, producing an average of 1.2 to $2.0 \mathrm{tha}^{-1}$ with half the required irrigation $[28,29]$. On the other hand, when a low irrigation strategy was used during all phenological stages this resulted in a 75\% reduction in seed yield of the quinoa cultivar 'Belen 2000' [28,29].

Our work obtained higher yield values than others reported in the literature, and under all WRs the genotypes with high productivity were CPAC13, CPAC6, CPAC3, CPAC12, and CPAC17 and the genotypes with lower yield potential were CPAC19, CPAC11, and CPAC14 [30,31]. Under higher WR $(480 \mathrm{~mm})$ the genotypes did not differ, with the exception of CPAC11, which presented the lowest productivity and low PUAA; however, CPAC11 was also the only dwarf material used in this study (see below) (Figure 2, Tables 1 and 2). For the $150 \mathrm{~mm}$ WR the CPAC17 genotype was superior to the other genotypes, and whilst productivity was altered there were no changes in efficiency between WR 150 and WR $389 \mathrm{~mm}$ (Table 1), meaning that it is a suitable genotype for use in situations with limited water availability such as the off-season.

Under high and intermediate water regimes, the highest PUAA was observed for CPAC3, CPAC6, and CPAC12 between WR 480 and WR $247 \mathrm{~mm}$ (Table 2) and considering that they were amongst the genotypes with highest productivity, these genotypes are suggested for the winter season. Specifically, CPAC6 exhibited reduced productivity only under the $247 \mathrm{~mm}$ WR (Table 1) and presented the highest PUAA of $26.7 \mathrm{~kg} \mathrm{ha}^{-1} \mathrm{~mm}^{-1}$. This value is $32 \%$ higher than the PUAA of WR $480 \mathrm{~mm}$ (Table 2). CPAC13 presented higher productive potential and productivity than BRS Piabiru under a moderate water regime $(389 \mathrm{~mm})$, with $9.73 \mathrm{t} \mathrm{ha}^{-1}$ for CPAC13 and $8.14 \mathrm{t} \mathrm{ha}^{-1}$ for BRS Piabiru, respectively. 


\subsection{The Effects of Water Regime and Genotype on Grain Quality Indicators}

In addition to productivity indicators of grain quality such as the concentrations of flavonoids and anthocyanins and 1000-grain weight should also be taken into account when selecting genotypes (Tables 3 and 4, Figure S1). Our results show that the accumulation of flavonoids and anthocyanins in quinoa plants was more influenced by genotype than by the WRs. In particular, CPAC9 accumulated these compounds under both higher and lower water regimes and accumulated nearly double the concentration of the other genotypes under all WRs. In addition, CPAC9 is among the genotypes with greater productivity and PUAA under high and intermediate WRs (Tables 1 and 2). The authors of [32], when studying the levels of flavonoids, phenolic acids, and betaines in the Andean grains of quinoa, kaniwa, and kiwicha, found flavonoid contents ranging from 36.2 to $144.3 \mathrm{mg} / 100 \mathrm{~g}$, which are similar than those found here. In other crops such as peanuts, depending on the genotype and drought period, concentrations of phenolic compounds in seeds may be between 60 and $220 \mathrm{mg} / 100 \mathrm{~g}$ [33]. Further studies focusing on the biosynthesis of phenolic compounds and oxidation processes under water stress will provide more information on the genotypic variation of phenolic content in grains [34]. Grain weight is also affected by water restriction. With a water supply of $150 \mathrm{~mm}$, there was a $14 \%$ decrease in TGW for the four genotypes analysed, similar to a previous study where TGW in irrigated plants was significantly higher $(5.5 \mathrm{~g})$ than in rainfed plants $(4.2 \mathrm{~g})[28,29]$. Indeed, when water stress is applied during the grain filling period, it generally reduces the grain yield, the number of grains per plant, and the individual weight of the grains [35].

\subsection{Low Water Availability Leads to Reduced Plant Height}

The heights of the quinoa genotypes in this study ranged from 0.99 to $1.53 \mathrm{~m}$, which are superior to those in literature [36]. Our results support previous studies demonstrating that a reduction in irrigation resulted in a significant decrease in plant height by 0.55 and $0.80 \mathrm{~m}$ for Bolivian quinoa [37]. Here, we detected a decrease in cultivated quinoa plant height under $70 \%$ irrigation deficit in relation to control plants, similar to that observed by [38]. The reduction of plant size and leaf area under stress conditions is directly related to a decline in dry mass when compared to plants maintained under adequate soil water potential conditions [39]. The low water potential of the soil limits water absorption capacity, and this quickly suppresses the rate of cell expansion and division of growing tissues [40]. Moreover, under severe water deficit stomata close and the consequent reduction of photosynthesis results in a decrease in dry mass production [39]. Plant height can also be used as a criterion to determine the susceptibility of quinoa genotypes to drought, as the longer the cycle, the larger the plant. Short-to-medium cycle cultivars are desirable, and would provide the possibility of more crops per year in irrigated systems [2] and enable off-season and winter planting. A shorter crop cycle also represents a method of escape from water stress under Cerrado conditions, besides contributing to the definition of the sowing season, such that the grain maturation occurs when the humidity is reduced, thus avoiding seed deterioration [2]. Amongst the studied genotypes, CPAC11 was significantly shorter. Whilst this is ideal for avoiding lodging, this genotype also showed the lowest productivity in most WRs under the planting density we employed. This may be related to reduced cell expansion, which results in a reduction in leaf area and, consequently, less photoassimilates for translocation to the grain [41]. In addition, water deficit affects carbohydrate utilization, altering the efficiency with which photoassimilates are used in the growth and development of new plant organs [41]. This genotype (CPAC11), however, may not have expressed its productive potential considering that it is the only dwarf material used in this study (Figure 2) and may need a higher planting density per square meter.

\subsection{Physiological Parameters}

Abiotic stresses generally result in reduced rates of photosynthesis and transpiration that can ultimately contribute to reduced growth and productivity [41], making assessment of physiological parameters in the field an important tool in screening for stress tolerance. 
For this reason, we analysed a number of physiological parameters in a subset of the quinoa genotypes. Remote sensing of leaf temperature by thermal imaging can be a reliable way to detect changes in the physiological state of plants in response to different biotic and abiotic stresses [42]. Indeed, canopy temperature has been used successfully in breeding programs for drought-prone environments [43,44], as genotypes that maintain transpiration will tend to have lower canopy temperature than other genotypes under the same environmental conditions in the field [45]. Here, reduced water availability led to increased canopy temperature, reflecting the stomatal closure and reduced transpiration that we detected using gas exchange analysis. However, we were not able to detect differences between the genotypes using this parameter (Figure S2), despite the fact that differences in transpiration were detected between genotypes at each WR (Table 5). It may be the case that larger differences in transpiration between genotypes are required to result in alterations in leaf temperature that can be measured using this technique.

Stomatal closure is a common response to water restriction where water deficit affects guard cell turgidity and stomatal aperture, resulting in decreases in the rates of transpiration and assimilation of $\mathrm{CO}_{2}$ and increased leaf temperature [46-48]. Gas exchange parameters such as net photosynthesis, transpiration and stomatal conductance are therefore sensitive indicators of water deficit in plants that are useful in the evaluation of genotypes adapted for growing in environments with limited water availability. Our data are consistent with previous studies, since the photosynthetic rate presented a behaviour similar to that observed for stomatal conductance and transpiration, reflecting the opening and closing of stomata under different water conditions [49], and quinoa is known to suffer both stomatal and mesophyll limitations under drought stress [50] These results also suggest that the reduction in photosynthetic rates in the most stressed water regimes are related to partial stomatal closure and a consequent reduction in $\mathrm{CO}_{2}$ assimilation (Table 5). Water stress is considered to be severe when stomatal conductance values are below 0.1 mol. $\mathrm{m}^{-2} \mathrm{~s}^{-1}$ [47], and therefore in this study all genotypes were under severe stress in the $150 \mathrm{~mm}$ WR (Table 5). Similar values for stomatal conductance and effects of water restriction in quinoa have been reported elsewhere; for example stomatal conductance decreased from $0.213 \mathrm{~mol} . \mathrm{m}^{-2} \mathrm{~s}^{-1}$ under irrigation to $0.091 \mathrm{~mol} . \mathrm{m}^{-2} \mathrm{~s}^{-1}$ under water deficit in one study [51] whilst an investigation of 10 genotypes in the field without irrigation that received around $160 \mathrm{~mm}$ of water reported values between 1.0 and $0.18 \mathrm{~mol} . \mathrm{m}^{-2}$ $\mathrm{s}^{-1}$ and a clear relationship between maintenance of stomatal conductance and higher photosynthetic rate [52].

Analysis of gas exchange also revealed differences in the responses of the genotypes to alterations in water availability and relationships with productivity. CPAC4 and CPAC11 appear most sensitive to water restriction as they presented the lowest net photosynthesis under the $150 \mathrm{~mm}$ and $247 \mathrm{~mm}$ regimes. Interestingly though, whilst CPAC19 showed greater photosynthesis under all water regimes, this was not reflected in greater productivity, indicating that other factors, such as plant morphology and the capacity to use photoassimilates for grain filling also has an important impact. This is also seen in the relationship between water regime, photosynthesis and productivity for individual genotypes; for example, the increased photosynthesis shown by CPAC4 between WR389 and WR480 did not translate into greater productivity, reinforcing the importance of parameters such as PUAA for selecting genotypes under irrigated conditions (Tables 1,2 and 5).

Gas exchange measurements may not always be able to detect the deleterious effects of water restriction on chloroplast function parameters such as the effective quantum yield of photosystem II potentially useful tools [53]. Here we detected decreased $\mathrm{F}^{\prime} \mathrm{v} / \mathrm{F}^{\prime} \mathrm{m}$ with low water availability (WR $150 \mathrm{~mm}$, Figure S3); this decrease in plants stressed by drought, in comparison with well-hydrated plants, is mainly due to the lack of $\mathrm{CO}_{2}$ inside the leaf and it is under this WR that we detected large decreases in Ci for all genotypes (Table 5). However, this parameter responded little to the median level of stress $(389 \mathrm{~mm})$, despite the fact that this WR provoked changes in several gas exchange parameters (Table 5), and furthermore we did not detect any differences between the genotypes (Figure S3). Indeed, 
measurements of chlorophyll a fluorescence tend to have low sensitivity to mild stresses, for example, 18 days of suspension of irrigation were required to reduce $\mathrm{Fv} / \mathrm{Fm}$ in two greenhouse-grown quinoa genotypes [53]. In contrast to $\mathrm{F}^{\prime} \mathrm{v} / \mathrm{F}^{\prime} \mathrm{m}$, chlorophyll indices proved to be unaffected by WR but showed differences between genotypes (Table S1), and lack of an effect of drought and flooding on chlorophyll in quinoa has previously been reported [52]. Despite the lack of an effect of stress on chlorophyll, these indices may prove useful for selection of genotypes due to the fact that chlorophyll abundance is typically positively related to photosynthetic potential and productivity [54]. In this sense of the four genotypes analysed CPAC19 stood out due to greater total chlorophyll and a lower chlorophyll a:b ratio that may indicate greater light absorption capacity by photosystem II [55].

A lack of water in the soil increases the risk of the rate of transpiration exceeding the rate of water absorption and transport, resulting in a situation of water deficit. Partial stomatal closure can reduced transpiration, but under water stress, plants often also accumulate compatible solutes or osmoprotectors including proline, glycine, betaine, and sugars [56]. The accumulation of compatible solutes reduces cellular osmotic potential, thereby permitting water absorption and maintaining turgor pressure and physiological processes [57]. The accumulation of proline may therefore be an important characteristic for the selection of drought-tolerant plants [58] and indeed seed or leaf treatment of quinoa plants with free proline can increase growth under water stress [59] whilst a number of studies have connected compatible proline accumulation with drought and salt tolerance in this species [49]. However, whilst we detected increased proline concentrations in quinoa in response to water stress, this only occurred under the most severe water regimes, meaning that it could not be used to discriminate between the genotypes under water regimes that reflect Cerrado conditions (Table S2). Despite morphological alterations, stomatal control and osmotic adjustment water restriction may eventually affect leaf water status. Leaf relative water content (RWC) can therefore be used to indicate the balance between water supply and transpiration [60], and in the case of $\mathrm{F}^{\prime} \mathrm{v} / \mathrm{F}^{\prime} \mathrm{m}$, we did not detect differences between the genotypes for this parameter (Figure S4). However, RWC did serve to indicate the degree of stress to which the plants were subject, as the RWC values detected below $389 \mathrm{~mm}$ correspond to those associated with the beginning of wilting (Figure S4, [20] and are similar to those observed in greenhouse grown plants during suspension of irrigation [53].

\section{Conclusions}

Through experiments performed under different water regimes here we have shown that quinoa has excellent potential for planting as an off-season and winter crop in the Cerrado region. Several genotypes presented advantages in relation to the currently used BRS Piabiru genotype; the choice of genotype will depend on farming practices, nutritional content, and weather conditions. CPAC13 and CPAC6 are particularly suited to growth as a winter crop under irrigated conditions, and CPAC17 under off-season rain-fed conditions, whilst CPAC9 appears advantageous in terms of phenolic compounds in the grains. The accumulation of flavonoids and anthocyanins in quinoa genotypes was more influenced by quinoa genotype than by the WRs. Analysis of physiological parameters provided information regarding the mechanisms involved in stress tolerance in different quinoa genotypes, which is essential if we are to develop strategies to maintain or increase plant productivity in environments with water limitation. The results of this work show that the water regimes for quinoa can be reduced without a significant reduction in grain yield. This increase in dry matter accumulation efficiency per unit of water applied in quinoa means it is a crop that can be cultivated under Cerrado conditions, for both the off-season and winter season, under relatively low levels of irrigation whilst obtaining high yields. This fact, coupled with proper water management this can result in higher yield per area, which is desirable for areas under irrigated cultivation where irrigation is a costly practice. 
Supplementary Materials: The following are available online at https: / www.mdpi.com/article/ 10.3390 / plants10081591/s1, Figure S1. Effects of water regimes in quinoa genotypes on 1000 grain weight- TWG (A). Weight of 1000 grains- TWG in four quinoa genotypes under four water regimes (B). Means followed by the same letter do not differ according to the Tukey test at $5 \%$ probability. Figure S2. Effects of water regimes $(150,247,389$ and $480 \mathrm{~mm})$ on leaf temperature. Figure S3. Effects of water regimes $(150,247,389$ and $480 \mathrm{~mm})$ on the effective quantum yield of photosystem II ( $\left.\mathrm{F}^{\prime} \mathrm{v} / \mathrm{F}^{\prime} \mathrm{m}\right)$ in quinoa geno-types. Figure S4. Effects of water regimes (150, 247, 389 and $480 \mathrm{~mm})$ on the relative water con-tent (RWC) in quinoa genotypes. Table S1: Chlorophyll $a, b, a / b e a+b$ measured in four quinoa genotypes independent of water regime (150, 247, 389 and $480 \mathrm{~mm})$. Table S2: Proline content $\left(\mu \mathrm{mol} \mathrm{g}^{-1} \mathrm{FM}\right)$ in leaves of four quinoa genotypes (CPAC4, CPAC 9, CPAC 11 e BRS Piabiru Pre-coce) under four water regimes $(150,247,389,480 \mathrm{~mm})$.

Author Contributions: Conceptualization, P.C.d.S., W.Q.R.J. and M.L.G.R.; methodology P.C.d.S., W.Q.R.J., C.A.d.L., M.L.G.R., R.A.d.C.N.C. and S.M.C.C.; formal analysis P.C.d.S., A.d.N.S., T.C.R.W. and C.C.V.; software R.A.d.C.N.C., C.C.S.; writing—original draft preparation, P.C.d.S., M.L.G.R., W.Q.R.J., T.C.R.W. and C.C.V. All authors have read and agreed to the published version of the manuscript.

Funding: This research received no external funding.

Data Availability Statement: Data is contained within the article and Supplementary Material.

Acknowledgments: To Conselho Nacional de Desenvolvimento Científico e Tecnológico (CNPq), for the scientific productitvity fellowships granted to Maria L G Ramos. Furthermore, to Coordenação de Aperfeiçoamento de Pessoal de Nível Superior for the Master and Pos Doc fellowship granted to Patricia C. Silva and Christina C. Vinson, respectively.

Conflicts of Interest: The authors declare that they have no conflict of interest.

\section{References}

1. Scheelbeek, P.F.; Bird, F.A.; Tuomisto, H.L.; Green, R.; Harris, F.B.; Joy, E.J.M.; Chalabi, Z.; Allemn, E.; Haines, A.; Dangour, A.D. Effect of environmental changes on vegetable and legume yields and nutritional quality. Proc. Natl. Acad. Sci. USA 2018, 115, 6804-6809. [CrossRef]

2. Soares, G.F.; Ribeiro, W.Q., Jr.; Pereira, L.F.; Lima, C.A.; Soares, D.D.S.; Muller, O.; Rascher, U.; Ramos, M.L.G. Characterization of wheat genotypes for drought tolerance and water use efficiency. Sci. Agric. 2021, 78, e20190304. [CrossRef]

3. Spehar, C.R.; Santos, R.L.B. Quinoa BRS Piabiru: Alternativa para diversificar os sistemas de produção de grãos. Pesq. Agropec. Bras. 2001, 37, 889-893. [CrossRef]

4. Garcia, R.A.; Ceccon, G.; Sutier, G.A.D.; Santos, A.L.F.D. Soybean-corn succession according to seeding date. Pesq. Agropec. Bras. 2018, 53, 22-29. [CrossRef]

5. Präger, A.; Munz, S.; Nkebiwe, P.M.; Mast, B.; Graeff-Hönninger, S. Yield and quality characteristics of different quinoa (Chenopodium quinoa Willd.) cultivars grown under field conditions in Southwestern Germany. Agronomy. 2018, 8, 197. [CrossRef]

6. Saad-Allah, K.M.; Youssef, M.S. Phytochemical and genetic characterization of five quinoa (Chenopodium quinoa Willd.) genotypes introduced to Egypt. Physiol. Mol. Biol. Plants 2018, 24, 617-629. [CrossRef]

7. Wang, D.; Cao, D.; Yao, Y.; Wang, J.; Li, Z.; Liu, B. Understanding the checmial foundation and genetic mecanism of the black grain trait in quinoa by integrating metabolome and transcriptome analyses. Biotechnol. Biotechnol. Equip. 2020, 34, 1095-1103. [CrossRef]

8. Razzaghi, F.; Bahadori-Ghasroldashti, M.R.; Henriksen, S.; Sepaskhah, A.R.; Jacobsen, S.E. Physiological characteristics and irrigation water productivity of quinoa (Chenopodium quinoa Willd.) in response to deficit irrigation imposed at different growing stages-A field study from Southern Iran. J. Agron. Crop Sci. 2020, 206, 390-404. [CrossRef]

9. Landi, M.; Tattini, M.; Gould, K.S. Multiple functional roles of anthocyanins in plant-environment interactions. Environ. Exp. Bot. 2015, 119, 4-17. [CrossRef]

10. Jayme-Oliveira, A.; Ribeiro, W.Q.; Ramos, M.L.G.; Ziviani, A.C.; Jakelaitis, A. Amaranth, quinoa, and millet growth and development under different water regimes in the Brazilian Cerrado. Pesq. Agropec. Bras. 2017, 52, 561-571. [CrossRef]

11. Bazile, D.; Pulvento, C.; Verniau, A.; Al-Nusairi, M.S.; Ba, D.; Breidy, J.; Hassan, L.; Mohammed, M.I.; Mambetov, O.; Otambekova, M.; et al. Worldwide evaluations of quinoa: Preliminary results from post international year of quinoa FAO projects in nine countries. Front. Plant Sci. 2016, 7, 850. [CrossRef]

12. FAO. The State of Food Insecurity in the World 2014; Food and Agriculture Organization of the United Nations: Rome, Italy, 2021. Available online: http:/ / www.fao.org/publications/sofi/en/ (accessed on 11 March 2021).

13. Alvares, C.A.; Stape, J.L.; Sentelhas, P.C.; Gonçalves, J.D.M. Köppen's climate classification map for Brazil. Meteorol. Z. 2013, 22, 711-728. [CrossRef]

14. Hanks, R.J.; Keller, J.; Rasmussen, V.P.; Wilson, G.D. Line source sprinkler for continuous variable irrigation crop production studies. Soil Sci. Soc. Am. J. 1976, 40, 426-429. [CrossRef] 
15. Embrapa-Empresa Brasileira de Pesquisa Agropecuária. Monitoramento de Irrigação no Cerrado. 2016. Available online: http:/ / hidro.cpac.embrapa.br (accessed on 25 May 2017).

16. QGIS Development Team; QGIS Geographic Information System. Open Source Geospatial Foundation Project; QGIS Development Team: Chur, Switzerland, 2021.

17. Secretaria de Defesa Agropecuária, Brasil Ministério da Agricultura, Pecuária e Abastecimento. Regras para Análise de Sementes; Brasil Ministério da Agricultura, Pecuária e Abastecimento: Brasília, Brazil, 2009.

18. Lees, D.H.; Francis, F.J. Standardization of pigment analyses in cranberries. HortScience 1972, 7, 83-84.

19. Genty, B.; Briantais, J.M.; Baker, N.R. The relationship between the quantum yield of photosynthetic electron transport and quenching of chlorophyll fluorescence. Biochim. Biophys. Acta Gen. Subj. 1989, 990, 87-92. [CrossRef]

20. Barrs, H.D.; Weatherley, P.E. A re-examination of the relative turgidity technique for estimating water deficits in leaves. Aust. J. Biol. Sci. 1962, 15, 413-428. [CrossRef]

21. Bates, L.S.; Waldren, R.P.; Teare, I.D. Rapid determination of free proline for water-stress studies. Plant Soil 1973, 39, $205-207$. [CrossRef]

22. SAS-Statistical Analyses System. Statistical Analysis System User's Guide; Institute, Statistical Analyses System: Cary, NC, USA, 2008.

23. SYSTAT Software. Scientific Graphing Software: Sigma Plot, Versão 10.0; HearneScientific Software: San Rafael, CA, USA, 2006.

24. Howell, T.A. Irrigation Efficiency. In Encyclopedia of Soil Science, 2nd ed.; CRC: Boca Raton, FL, USA, 2003.

25. Zhang, M.; Duan, L.; Tian, X.; He, Z.; Li, J.; Wang, B.; Li, Z. Uniconazole-induced tolerance of soybean to water deficit stress in relation to changes in photosynthesis, hormones and antioxidant system. J. Plant Physiol. 2007, 164, 709-717. [CrossRef] [PubMed]

26. Vacher, J.J. Responses of two main Andean crops, quinoa (Chenopodium quinoa Willd) and papa amarga (Solanum juzepczukii Buk.) to drought on the Bolivian Altiplano: Significance of local adaptation. Agric. Ecosyst. Environ. 1998, 68, 99-108. [CrossRef]

27. Yousfi, S.; Serret, M.D.; Araus, J.L. Shoot $\delta(15) \mathrm{N}$ gives a better indication than ion concentration or $\Delta(13) \mathrm{C}$ of genotypic differences in the response of durum wheat to salinity. Funct. Plant Biol. 2009, 36, 144-155. [CrossRef] [PubMed]

28. Geerts, S.; Raes, D.; Garcia, M.; Condori, O.; Mamani, J.; Miranda, R.; Cusicanqui, J.; Taboada, C.; Yucra, E.; Vacher, J. Could deficit irrigation be a sustainable practice for quinoa (Chenopodium quinoa Willd.) in the Southern Bolivian Altiplano? Agric. Water Manag. 2008, 95, 909-917. [CrossRef]

29. Geerts, S.; Raes, D.; Garcia, M.; Vacher, J.; Mamani, R.; Mendoza, J.; Huanca, R.; Morales, B.; Miranda, R.; Cusicanqui, J.; et al. Introducing deficit irrigation to stabilize yields of quinoa (Chenopodium quinoa Willd.). Eur. J. Agron. 2008, 28, 427-436. [CrossRef]

30. Martínez, E.A.; Veas, E.; Jorquera, C.; San Martín, R.; Jara, P. Re-introduction of quinoa into Arid Chile: Cultivation of two lowland races under extremely low irrigation. J. Agron. Crop Sci. 2009, 195, 1-10. [CrossRef]

31. Delgado, A.I.; Palacios, J.H.; Betancourt, C. Evaluation of 16 genotypes of sweet quinoa (Chenopodium quinoa Willd.) in the municipality of Iles, Nariño (Colombia). Agron. Colomb. 2009, 27, 159-167.

32. Repo-Carrasco-Valencia, R.; Hellström, J.K.; Pihlava, J.M.; Mattila, P.H. Flavonoids and other phenolic compounds in Andean indigenous grains: Quinoa (Chenopodium quinoa), kañiwa (Chenopodium pallidicaule) and kiwicha (Amaranthus caudatus). Food Chem. 2010, 120, 128-133. [CrossRef]

33. Aninbon, C.; Jogloy, S.; Vorasoot, N.; Patanothai, A.; Nuchadomrong, S.; Senawong, T. Effect of end of season water deficit on phenolic compounds in peanut genotypes with different levels of resistance to drought. Food Chem. 2016, 196, 123-129. [CrossRef]

34. Martini, D.; Taddei, F.; Nicoletti, I.; Ciccoritti, R.; Corradini, D.; D’Egidio, M.G. Effects of genotype and environment on phenolic acids content and total antioxidant capacity in durum wheat. Cereal Chem. 2014, 91, 310-317. [CrossRef]

35. Gámez, A.L.; Soba, D.; Zamarreño, Á.M.; García-Mina, J.M.; Aranjuelo, I.; Morales, F. Effect of water stress during grain filling on yield, quality and physiological traits of Illpa and Rainbow quinoa (Chenopodium quinoa Willd.) cultivars. Plants 2019, 8, 173. [CrossRef]

36. Maliro, M.F.; Guwela, V.F.; Nyaika, J.; Murphy, K.M. Preliminary studies of the performance of quinoa (Chenopodium quinoa Willd.) genotypes under irrigated and rainfed conditions of central Malawi. Front. Plant Sci. 2017, 8, 227. [CrossRef]

37. Talebnejad, R.; Sepaskhah, A.R. Effect of deficit irrigation and different saline groundwater depths on yield and water productivity of quinoa. Agric. Water Manag. 2015, 159, 225-238. [CrossRef]

38. Yang, A.; Akhtar, S.S.; Amjad, M.; Iqbal, S.; Jacobsen, S.E. Growth and physiological responses of quinoa to drought and temperature stress. J. Agron. Crop Sci. 2016, 202, 445-453. [CrossRef]

39. Endres, L. Photosynthesis and water relations in Brazilian sugarcane. Open Agric. J. 2010, 4, 31-37. [CrossRef]

40. Shao, H.B.; Chu, L.Y.; Shao, M.A.; Jaleel, C.A.; Hong-mei, M. Higher plant antioxidants and redox signaling under environmental stresses. Comptes Rendus Biol. 2008, 331, 433-441. [CrossRef] [PubMed]

41. Jordan, W.R. Whole Plant Response to Water Deficits: An Overview. Limit. Effic. Water Use Crop. Prod. 1983, 289-317. [CrossRef]

42. Li, C.; Liu, S.; Berninger, F. Picea seedlings show apparent acclimation to drought with increasing altitude in the eastern Himalaya. Trees Struct. Funct. 2004, 18, 277-283. [CrossRef]

43. Balota, M.; Payne, W.A.; Evett, S.R.; Peters, T.R. Morphological and physiological traits associated with canopy temperature depression in three closely related wheat lines. Crop Sci. 2008, 48, 1897-1910. [CrossRef]

44. Jones, H.G.; Serraj, R.; Loveys, B.R.; Xiong, L.; Wheaton, A.; Price, A.H. Thermal infrared imaging of crop canopies for the remote diagnosis and quantification of plant responses to water stress in the field. Funct. Plant Biol. 2009, 36, 978-989. [CrossRef] 
45. Blum, A. Effective use of water (EUW) and not water-use efficiency (WUE) is the target of crop yield improvement under drought stress. Field Crops Res. 2009, 112, 119-123. [CrossRef]

46. Waseem, M.; Ali, A.; Tahir, M.; Nadeem, M.A.; Ayub, M.; Tanveer, A.; Ahmad, R.; Hussain, M. Mechanism of drought tolerance in plant and its management through different methods. Cont. J. Agric. Sci. 2011, 5, 10-25.

47. Flexas, J.; Diaz-Espejo, A.; Gago, J.; Gallé, A.; Galmés, J.; Gulías, J.; Medrano, H. Photosynthetic limitations in Mediterranean plants: A review. Environ. Exp. Bot. 2014, 103, 12-23. [CrossRef]

48. Tatagiba, S.D.; Pezzopane, J.E.M.; Reis, E.F. Fotossíntese em Eucalyptus sob diferentes condições edafoclimáticas. Rev. Eng. Agric. RevEng 2015, 23, 336-345. [CrossRef]

49. Hinojosa, L.; González, J.A.; Barrios-Masias, F.H.; Fuentes, F.; Murphy, K.M. Quinoa Abiotic Stress Responses: A Review. Plants 2018, 7, 106. [CrossRef]

50. Killi, D.; Haworth, M. Diffusive and metabolic constraints to photosynthesis in quinoa during drought and salt stress. Plants 2017, 6, 49. [CrossRef] [PubMed]

51. Hussin, S.; Khalifa, W.; Geissler, N.; Koyro, H.W. Influence of the root endophyte Piriformospora indica on the plant water relations, gas exchange and growth of Chenopodium quinoa at limited water availability. J. Agron. Crop Sci. 2017, 203, 373-384. [CrossRef]

52. González, J.A.; Gallardo, M.; Hilal, M.B.; Rosa, M.D.; Prado, F.E. Physiological responses of quinoa (Chenopodium quinoa) to drought and waterlogging stresses: Dry matter partitioning. Bot. Stud. 2009, 50, 35-42.

53. Morales, A.; Zurita-Silva, A.; Maldonado, J.; Silva, H. Transcriptional responses of Chilean quinoa (Chenopodium quinoa Willd.) under water deficit conditions uncovers ABA-independent expression patterns. Front. Plant Sci. 2017, 8, 216. [CrossRef]

54. O'Neill, P.M.; Shanahan, J.F.; Schepers, J.S. Use of chlorophyll fluorescence assessments to differentiate corn hybrid response to variable water conditions. Crop Sci. 2006, 46, 681-687. [CrossRef]

55. Belous, O.; Klemeshova, K.; Malyarovskaya, V. Photosynthetic Pigments of Subtropical Plants. In Photosynthesis—From Its Evolution to Future Improvements in Photosynthetic Efficiency Using Nanomaterials; IntechOpen Limited: London, UK, 2018; pp. 31-52.

56. Nounjan, N.; Chansongkrow, P.; Charoensawan, V.; Siangliw, J.L.; Toojinda, T.; Chadchawan, N.; Chansongkrow, P.; Charoensawan, V.; Siangliw, J.L.; Toojinda, T.; et al. High performance of photosynthesis and osmotic adjustment are associated with salt tolerance ability in rice carrying drought tolerance QTL: Physiological and co-expression network analysis. Front. Plant Sci. 2018, 9, 1135. [CrossRef] [PubMed]

57. Pintó-Marijuan, M.; Munné-Bosch, S. Ecophysiology of invasive plants: Osmotic adjustment and antioxidants. Trends Plant Sci. 2013, 18, 660-666. [CrossRef]

58. Ben Rejeb, K.; Abdelly, C.; Savouré, A. How reactive oxygen species and proline face stress together. Plant Physiol. Biochem. PPB 2014, 80, 278-284. [CrossRef] [PubMed]

59. Yaqoob, H.; Akram, N.A.; Iftikhar, S.; Ashraf, M.; Khalid, N.; Sadiq, M.; Alyemeni, M.N.; Wijaya, L.; Ahmad, P. Seed pretreatment and foliar application of proline regulate morphological, physio-biochemical processes and activity of antioxidant enzymes in plants of two cultivars of quinoa (Chenopodium quinoa Willd.). Plants 2019, 8, 588. [CrossRef] [PubMed]

60. Lugojan, C.; Ciulca, S. Evaluation of relative water content in winter wheat. For. Biotechnol. 2011, 15, $173-177$. 